\title{
p53 Activation Domain 1 Is Essential for PUMA Upregulation and p53-Mediated Neuronal Cell Death
}

\author{
Sean P. Cregan, ${ }^{\star}$ Nicole A. Arbour, ${ }^{\star}$ Jason G. MacLaurin, Steven M. Callaghan, Andre Fortin, Eric C. C. Cheung, \\ Daniel S. Guberman, David S. Park, and Ruth S. Slack \\ Ottawa Health Research Institute-Neuroscience Centre and Department of Cellular and Molecular Medicine, University of Ottawa, Ottawa, Ontario, K1H \\ 8M5 Canada
}

The $p 53$ tumor suppressor gene has been implicated in the regulation of apoptosis in a number of different neuronal death paradigms. Because of the importance of $\mathrm{p} 53$ in neuronal injury, we questioned the mechanism underlying p53-mediated apoptosis in neurons. Using adenoviral-mediated gene delivery, reconstitution experiments, and mice carrying a knock-in mutation in the endogenous $p 53$ gene, we show that the transactivation function of p53 is essential to induce neuronal cell death. Although p53 possesses two transactivation domains that can activate 53 targets independently, we demonstrate that the first activation domain (ADI) is required to drive apoptosis after neuronal injury. Furthermore, the BH3-only proteins Noxa and PUMA exhibit differential regulation by the two transactivation domains. Here, we show that Noxa can be induced by either activation domain, whereas PUMA induction requires both activation domains to be intact. Unlike Noxa, the upregulation of PUMA alone is sufficient to induce neuronal cell death. We demonstrate, therefore, that the first transactivation domain of p53 is indispensable for the induction of neuronal cell death.

Key words: apoptosis; Noxa; PUMA; p53; neuronal cell death; PERP

\section{Introduction}

The $p 53$ tumor suppressor gene is upregulated in multiple neuronal death paradigms including ischemia (Chopp et al., 1992; Cheng et al., 2003), hypoxia (Banasiak and Haddad, 1998; Halterman and Federoff, 1999), and excitotoxicity (Xiang et al., 1998; Cregan et al., 1999). Overexpression of p53 alone is sufficient to trigger apoptosis in postmitotic neurons (Slack et al., 1996; Cregan et al., 1999); consistent with this, p53 null mice exhibit reduced brain damage after excitotoxicity and stroke (Crumrine et al., 1994; Morrison et al., 1996). These studies emphasize the importance of p53 as a key apoptotic factor after neuronal injury.

It has become clear that the apoptotic mechanisms induced by p53 depends on the tissue type and insult (for review, see Ryan et al., 2001). p53 can function as a transcription factor; however, its requirement for the induction of apoptosis remains controversial. p53 contains two distinct activation domains (ADI and

Received June 1, 2004; revised Sept. 20, 2004; accepted Sept. 21, 2004.

This work was supported by grants from the Canadian Institutes of Health Research (CIHR) and the Heart and Stroke Foundation of Ontario to R.S.S and in part by a CIHR grant to S.P.C. Adenoviral vectors were generated by the Viral Vector Core Facility supported by grants from the Canadian Stroke Network to D.S.P. and R.S.S. S.P.C. was supported by a CIHR postdoctoral fellowship, and N.A.A. was supported by an Ontario Neurotrauma studentship. A.F. was supported by a Canadian Stroke Network studentship. D.S.P. is a GlaxoWelcome professor. We thank Victoria Sillberg for assistance in preparing neuronal cell cultures and Kerry Ferguson for critical review of this manuscript.

*S.P.C. and N.A.A. contributed equally to this work.

Correspondence should be addressed to either of the following: Dr. Ruth S. Slack, Ottawa Health Research Institute, University of Ottawa, 451 Smyth Road, Ottawa, Ontario, K1H 8M5 Canada, E-mail: rslack@uottawa.ca; or Dr. Sean P. Cregan, Robarts Research Institute, Cell Biology, P.0. Box 5015, 100 Perth Drive, London, Ontario, N6A 5K8 Canada, E-mail: scregan@robarts.ca.

DOI:10.1523/JNEUROSCI.2114-04.2004

Copyright $\odot 2004$ Society for Neuroscience 0270-6474/04/2410003-10\$15.00/0
ADII). Studies involving ectopic expression of p53 proteins containing inactivating deletions or mutations within ADI have generated conflicting results. It has been shown that the transcriptional function of ADI is essential for the induction of apoptosis in certain cellular systems (Attardi et al., 1996; Jimenez et al., 2000), but not in others (Haupt et al., 1995; Chen et al., 1996; Ding et al., 2000). Furthermore, it has been shown that mutations in ADII can diminish apoptotic activity and arrest cells in the $\mathrm{G}_{1}$ phase of the cell cycle (Zhu et al., 2000). In some systems, therefore, p53-mediated apoptosis requires ADI to be intact.

In addition to its role in transactivation, there is increasing evidence that $\mathrm{p} 53$ is capable of transcriptional repression, further suggesting the importance of p53 in regulating gene expression during apoptotic cell death (Seto et al., 1992; Murphy et al., 1996; Venot et al., 1998; Koumenis et al., 2001; Nakade et al., 2004). p53 has also been shown to induce cell death in a transcriptionally independent manner (Caelles et al., 1994; Haupt et al., 1995; Bennett et al., 1998). Studies have shown that 553 can function at the mitochondrial level (Marchenko et al., 2000; Mihara et al., 2003; Bonini et al., 2004; Chipuk et al., 2004). Differences in cell type and apoptotic stimulus may account for the variability in the required mechanism by which $p 53$ induces apoptosis. In summary, there are several $p 53$-dependent apoptotic pathways: one requiring transactivation, a second that functions through transcriptional repression, and a third that functions exclusively at the mitochondrial level.

Despite the importance of $p 53$ in the regulation of neuronal apoptosis, little is known regarding the mechanisms by which p53 mediates apoptosis in postmitotic neurons. In view of the diverse mechanisms by which p53 functions, in this study we questioned the mechanism underlying p53-mediated apoptosis in neurons. 
Table 1. Primer sequences for RT-PCR gene expression analysis

\begin{tabular}{lll}
\hline & Sequence & \\
\cline { 2 - 3 } Gene & 5'-Sense-3' $^{\prime}$ & 5' $^{\prime}$-Antisense-3' \\
\hline NOXA & CAACGCGGGCAGAGCTACCTGA & TGGGCTTGGGCTCCTCATCCTGCTC \\
APAF-1 & GACATCAAAACATCCTACATCA & CTTCCGCAGCTAACACAG \\
PUMA & CCTCAGCCCTCCCTGTCACCAG & CCGCCGCTCGTACTGCGCGTTG \\
PERP & ATCCTGCCCCTGCTGCTGCTCA & GGCGGCCCCCAAAGGTCATC \\
S12 & GGAAGGCATAGCTGCTGG & CCTCGATGACATCCTTGG \\
\hline
\end{tabular}

Our results demonstrate that the transactivational function of p53 is essential to induce neuronal cell death. Although two distinct domains have been identified, ADI is critical for the induction of the BH3-only Bcl-2 family member PUMA, which is required to drive neuronal cell death.

\section{Materials and Methods}

Cell culture and recombinant adenovirus infection. Cortical and cerebellar granule neurons (CGNs) were cultured as described previously (Cregan et al., 1999; Fortin et al., 2001). The cDNA for WTp53, p53 $\Delta$ I (Kubbutat et al., 1997), p53 $\Delta$ V, p53 $\Delta$ Pro, and p53 $22 / 23$ was a kind gift from Dr. Karen Vousden (Beatson Laboratories, Glasgow, UK). The p53 double transactivation mutant $\mathrm{p} 53 \Delta \mathrm{DM}$ was generously provided by Dr. Xinbin Chen (University of Alabama, Birmingham, AL). To generate the mutation for the second activation domain (ADII) alone (p53 $553 / 54)$, WTp53 cDNA was digested with BsrDI, and the resulting $5^{\prime}$ fragment was ligated to the corresponding 3' cDNA fragment from BsrDI-digested p53 $\Delta$ DM. The cDNA for Noxa and cDNA for HA-PUMA were kind gifts from Dr. Eri Oda (University of Tokyo, Tokyo, Japan) (Oda et al., 2000) and Dr. Bert Vogelstein (Howard Hughes Medical Institute/Johns Hopkins University, Baltimore, MD) ( $\mathrm{Yu}$ et al., 2001), respectively. N-terminal 3xFlag tag was added by subclonning full-length Noxa cDNA into p3XFLAG-myc-CMV-24 (Sigma, St. Louis, MO). Recombinant adenoviral vectors carrying expression cassettes for Noxa, PUMA, wildtype, or mutant human p53 proteins were constructed, purified, and titered as described previously (Cregan et al., 2000). Adenoviral vectors were added to cell suspensions immediately before plating.

Mice and genotyping. Mice carrying a targeted null mutation for P53 were obtained from The Jackson Laboratory (Bar Harbor, ME), and p53 genotyping was done by PCR, as described previously (Fortin et al., 2001). p53QS mice expressing p53 containing point mutations at codons 25 and 26 (L25Q,W26S) were a generous gift from Dr. Geoffrey Wahl (The Salk Institute, La Jolla, CA). Genotyping of these mice was performed as described previously (Jimenez et al., 2000). Mice carrying a targeted null mutation for PUMA were a generous gift from Dr. Andreas Strasser (The Walter and Eliza Hall Institute of Medical Research, Victoria, Australia), and genotyping of these mice was performed as described previously (Villunger et al., 2003).

Semiquantitative reverse transcription-PCR analysis. Total RNA was isolated from cells using Trizol isolation reagent according to the manufacturer's instructions (Invitrogen, San Diego, CA). Pilot experiments were performed to determine the linear range of amplification with respect to quantity of starting template and PCR cycles. The primers used for the detection of p53-inducible genes are shown in Table 1. Twentyfive to $100 \mathrm{ng}$ of total RNA were used for cDNA synthesis and targeted gene amplification using the SuperScript One-Step RT-PCR kit (Invitrogen). cDNA synthesis was performed at $48^{\circ} \mathrm{C}$ for $45 \mathrm{~min}$, followed by a 2 min initial denaturation step at $94^{\circ} \mathrm{C}$. This was followed by 35 cycles (Noxa), 30 cycles (APAF-1, PUMA, PERP), or 25 cycles (S12) at $94^{\circ} \mathrm{C}$ for $30 \mathrm{sec}, 55-62^{\circ} \mathrm{C}$ for $30 \mathrm{sec}$, and $72^{\circ} \mathrm{C}$ for $1 \mathrm{~min}$. The resulting products were sequenced to confirm identity.

Electrophoretic mobility shift assays. Electrophoretic mobility shift assays (EMSAs) were performed on total protein extracts as described (Fortin et al., 2001), with the following modifications. Cells were harvested, centrifuged, extracted in lysis buffer (100 mM HEPES, pH 7.4, $5 \mathrm{~mm}$ $\mathrm{MgCl}_{2}, 2.5 \mathrm{~mm}$ EDTA, 20\% glycerol, $0.5 \mathrm{M} \mathrm{KCl,} 0.5 \mathrm{~mm}$ PMSF, $0.1 \%$ $\mathrm{NP}-40,5 \mu \mathrm{g} / \mathrm{ml}$ aprotinin, $2 \mu \mathrm{g} / \mathrm{ml}$ leupeptin, and $20 \mu \mathrm{M}$ sodium orthovanadate), and assayed for protein concentration by the method of
Bradford (protein assay reagent; Bio-Rad, Hercules, CA). Protein extract $(10-20 \mu \mathrm{g})$ was incubated with an excess of indicated ${ }^{32} \mathrm{P}$-labeled double-stranded DNA probes $(60,000 \mathrm{cpm} / 0.2 \mathrm{ng}$ of DNA). The oligonucleotides used included 5'-ATGGAGGCACGTCCCCAGCGACAGCAGGCTC-3' (APAF1) and 5' - CCTGCCTTGCCTGGACTTGC-3' (P21) corresponding to the p53 consensus binding sequences within the Apaf-1 (Fortin et al., 2001) and p21 (Macleod et al., 1996) promoters, respectively. The binding reaction $(25 \mu \mathrm{l})$ was performed at room temperature for $20 \mathrm{~min}$ in binding buffer ( $50 \%$ glycerol, $250 \mathrm{mM} \mathrm{KCl,} 100$ mm HEPES, pH 7.4, 5 mm DTT, 5 mg/ml BSA, and 0.5\% Triton X-100) with $0.1 \mu \mathrm{g}$ of sonicated herring sperm DNA, and $1 \mu$ l of p53 Pab421 monoclonal antibody was added to the binding buffer (Ab-1; Oncogene Research Products, Uniondale, NY). To control for binding specificity, a 100-fold excess of unlabeled oligonucleotide was added to the binding reaction and incubated for $20 \mathrm{~min}$ before the addition of labeled probe. Complexes were resolved on a $5 \%$ polyacrylamide, $1 \times$ Tris-glycine gel, dried, and visualized by autoradiography.

Western blot analysis and immunostaining. Cells were fixed and permeabilized in ice-cold methanol for $20 \mathrm{~min}$, rehydrated in three changes of PBS, and incubated for $2 \mathrm{hr}$ with primary antibody to p53 (CM1; NovaCastra Laboratories, Newcastle, UK) or Cox IV (Molecular Probes, Eugene, OR). Cells were washed with PBS and then incubated for $1 \mathrm{hr}$ with Alexa 488- and/or Alexa 546-conjugated secondary antibodies (Molecular Probes). Cells were again washed in PBS and counterstained with Hoechst. Western blot analysis was performed as described previously (Cregan et al., 1999), with antibodies against p53 (CM1; Novacastra Laboratories), Flag (Sigma), hemagglutinin (HA) (Santa Cruz Biotechnology, Santa Cruz, CA) and actin (SC-1616; Santa Cruz Biotechnology) as a loading control.

Cell viability and caspase assays. Cell survival was measured by three methods: LIVE/DEAD, terminal deoxynucleotidyl transferase (TdT)mediated biotinylated UTP nick end labeling (TUNEL), and MTT assays. At the times indicated, neuronal viability was determined using the LIVE/DEAD viability/cytotoxicity kit (Molecular Probes) following the manufacturer's instructions. TUNEL was used to visualize cells with fragmented DNA. At the indicated times after treatment, cells were fixed in $4 \%$ paraformaldehyde for $20 \mathrm{~min}$, washed in three changes of PBS, and then incubated for $1 \mathrm{hr}$ at $37^{\circ} \mathrm{C}$ with $75 \mu \mathrm{l}$ of a mixture (Roche Diagnostics, Laval, Quebec, Canada) consisting of $0.5 \mu$ l of terminal transferase, $0.95 \mu$ l of biotin-16-dUTP, $6.0 \mu$ l of $\mathrm{CoCl}_{2}, 15.0 \mu \mathrm{l}$ of $5 \times \mathrm{TdT}$ buffer, and $52.55 \mu \mathrm{l}$ of distilled water. The reaction was stopped by incubation in $4 \times$ SSC buffer, followed by three washes in PBS. Cells were then labeled with a streptavidin-cyanine 2 secondary antibody (Jackson ImmunoResearch, West Grove, PA) for $45 \mathrm{~min}$ at room temperature and counterstained with Hoechst $33258(1 \mu \mathrm{g} / \mu \mathrm{l})$ for $5 \mathrm{~min}$. Images were captured using a Zeiss (Oberkochen, Germany) Axiovert 100 equipped with a Sony (Tokyo, Japan) HAD 3CCD power color video camera and analyzed using Northern Eclipse software. The fraction of TUNEL-positive cells as a percentage of total cell number was determined. For both the LIVE/DEAD and TUNEL assays, a minimum of 500 cells was scored for each treatment, and the data represent the mean and SD from a minimum of three independent experiments. In certain experiments, viability was assessed using the colorimetric MTT survival assay (Cell Titer kit; Promega, Madison, WI) that measures the mitochondrial conversion of the tetrazolium salt to a blue formizan salt, used as described previously (Slack et al., 1996).

For the caspase activity assay, cells were harvested and extracted in caspase lysis buffer ( $1 \mathrm{~mm} \mathrm{KCl,} 10 \mathrm{~mm}$ HEPES, pH 7.4, $1.5 \mathrm{~mm} \mathrm{MgCl}_{2}, 1$ mm DTT, $1 \mathrm{~mm}$ PMSF, $5 \mu \mathrm{g} / \mathrm{ml}$ leupeptin, $2 \mu \mathrm{g} / \mathrm{ml}$ aprotinin, and $10 \%$ glycerol) for $15 \mathrm{~min}$ on ice, and $10 \mu \mathrm{g}$ of protein was used to determine caspase activity as described previously (Cregan et al., 1999). Caspase activity is reported as the ratio of fluorescence output in treated samples relative to corresponding untreated controls.

\section{Results}

\section{Transcriptional activation is essential for p53-mediated} neuronal cell death

P53 is a multifunctional protein, the mechanism of action of which depends on the cell type or the death stimulus. To under- 


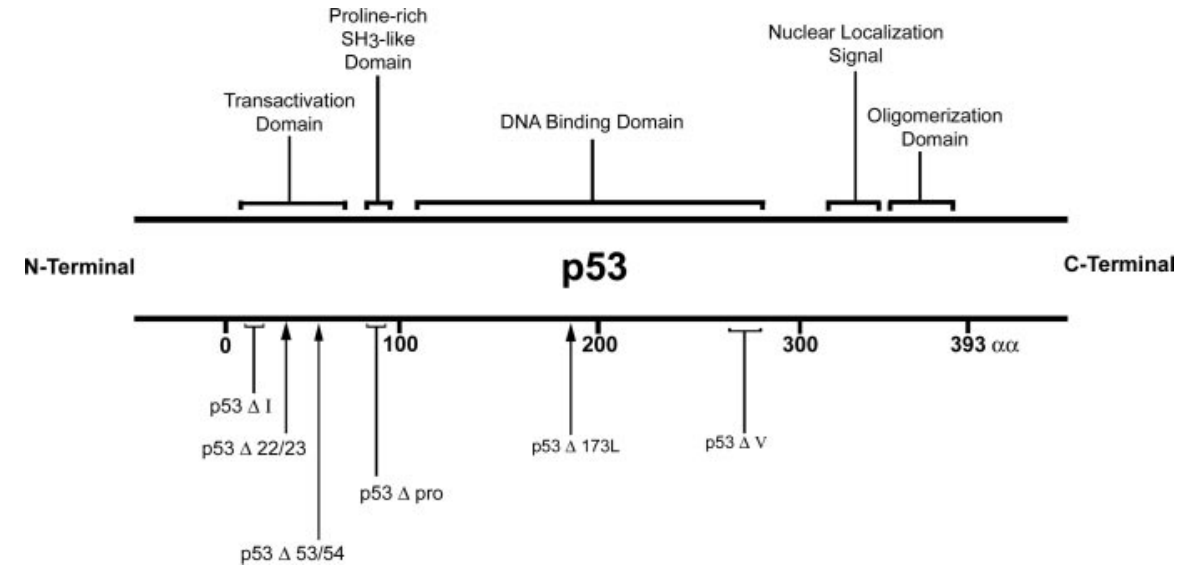

Figure 1. Schematic representation of $p 53$ constructs. Various $p 53$ constructs were used to determine the importance of each functional domain for neuronal apoptosis. The $\mathrm{p} 53 \Delta \mathrm{I}$ construct contains a deletion of the conserved box 1 sequence, which abolishes MDM2 binding without affecting DNA-binding activity. The p53 $\Delta 22 / 23$ construct contains two inactivating point mutations within the first transactivation domain (ADI); residues 22 and 23 were mutated from Leu and Trp to Glu and Ser, respectively. p53 $\Delta 53 / 54$ has mutations at residues 53 and 54 from Trp and Glu to Phe and Ser, respectively, which inactivates the second transactivation domain (ADII). The p53DM contains both transactivation domain mutations (p53- $\Delta 22 / 23$ and p53- $\Delta 53$ / 54). $p 53 \Delta$ Pro is a deletion of the proline-rich region of the $p 53$ protein, the $P 53-\Delta 173 \mathrm{~L}$ mutant has a point mutation at residue 173 to Leu, and $p 53 \Delta V$ is a deletion of the conserved box $V$ sequence of $p 53$, resulting in inactivation of DNA binding.

(Fig. 3B). These studies show that, in neuronal cells, p53 does not localize to the mitochondria and functions primarily in the nucleus. The following results demonstrating the requirement of an intact transactivation domain further support this conclusion.

To determine which functional domains of $\mathrm{p} 53$ are required for the induction of neuronal cell death, CGNs were transduced with adenoviral vectors expressing wild-type or mutant p53 proteins and assessed for apoptosis. After direct expression of p53, cells were assayed for caspase activation, by $N$-acetyl-Asp-Glu-Val-Asp-7-amino-4trifluromethyl-coumarin (DEVD-AFC) cleavage, and for survival, using two independent assays, LIVE/DEAD staining and TUNEL (Fig. 4A, $B, D$ ). Caspase activity closely paralleled cell death assays (Fig. $4 C)$. The most efficient constructs for inducing caspase activation and apoptosis were Ad-p53wt and Ad-p53 II. This was expected because Ad-p53 $\Delta \mathrm{I}$ lacks the mouse double minute 2 (MDM2)-binding

stand the mechanism by which p53 participates in injuryinduced neuronal death, we determined which functional domains were required for the induction of apoptosis. We constructed a panel of adenoviral vectors carrying wild-type and specific deletion/point mutants of p53 (Fig. 1). To facilitate a functional comparison between these constructs, we first verified that all p53 mutants (1) were expressed at comparable levels in CGNs by Western blot analysis and immunohistochemistry, (2) retained the correct conformation by performing EMSAs, and (3) were localized to the appropriate cellular compartment by immunofluorescence and confocal microscopy.

Western blot analysis revealed that all p53 mutant proteins were expressed, in CGNs, at levels comparable with wild-type p53 (Fig. $2 \mathrm{~A}$ ), and immunohistochemistry demonstrated that all the adenoviral constructs demonstrate comparable infectivity (Fig. $2 B$ ). To ensure that the protein conformation was not disrupted by specific deletions or site-directed mutagenesis, p53 sequencespecific DNA-binding activity was analyzed by EMSA. All p53 mutants, except the DNA-binding mutant Ad-p $53 \Delta \mathrm{V}$, could effectively bind DNA exhibiting complex formation comparable with that seen with wild-type p53 (Fig. 2C). Finally, because none of these mutants disrupted the nuclear localization domain, they localized appropriately to the nucleus (Fig. $3 A$ ). These experiments demonstrate that the p53 mutants used in this study are equally stable and maintain an appropriate protein conformation.

Recently, studies have revealed that p53 could translocate to the mitochondria and was capable of inducing apoptosis exclusively at this site (Marchenko et al., 2000; Sansome et al., 2001; Mihara et al., 2003; Bonini et al., 2004). To determine whether wild-type $\mathrm{p} 53$ or any of the mutant $\mathrm{p} 53$ proteins were targeted to the mitochondria, neurons were labeled with antibodies directed against p53 and a mitochondrial marker, $\alpha$-CoxIV. Analysis of p53 immunostaining by confocal microscopy revealed p53 localization exclusively within the nucleus. No colocalization with the mitochondria was found with overexpressed wild-type p53, even when nuclear condensation was evident, nor was there colocalization with the double transactivation mutant Ad-p53 DDM domain, which should enhance protein stability and thereby promote apoptotic activity. Loss of the proline-rich motif impaired apoptotic activity, revealing only partial caspase activation and TUNEL staining. Because p53 has two transactivation domains, we examined the importance of these domains in the induction of apoptosis. Inactivation of either domain resulted in a significant decrease in p53-induced apoptosis. However, inhibition of AD1 appeared to have a more profound effect on the ability of p53 to induce cell death (Fig. $4 A$ ). Cells expressing p53 $\Delta 22 / 23$ exhibited only $23 \%$ apoptosis at $72 \mathrm{hr}$ relative to wild-type $\mathrm{p} 53$, which led to $>63 \%$ cell death by $72 \mathrm{hr}$. In contrast, mutation of the second transactivation domain, Ad-p53 $53 / 54$, resulted in a more modest reduction in apoptotic activity with $\sim 34 \%$ of cells dying by 72 $\mathrm{hr}$. When both transactivation domains were inactivated (Adp53 DDM), there was no detectable increase in caspase activity or apoptotic death relative to control cells expressing Ad-GFP (green fluorescent protein). Similarly, the DNA-binding domain mutant p $53 \Delta V$ was apoptotically inert. In fact, the p53 $\Delta \mathrm{DM}$ and p $53 \Delta \mathrm{V}$ mutants were unable to induce caspase activation or cell death even when the time course was extended to $96 \mathrm{hr}$. In conclusion, the results of these studies demonstrate that neuronal apoptosis induced by direct expression of p53 requires DNAbinding activity and an intact transcriptional activation domain. Furthermore, the results suggest that ADI may play a more prominent role in the transcriptional induction of proapoptotic genes.

\section{Reconstitution of responsiveness to DNA damage-induced apoptosis in p53-deficient neurons}

It is well known that p53 function can be modulated by posttranslational modifications or the coactivation of other death signals (Morris et al., 2001; Xu, 2003). We therefore examined the function of wild-type and mutant $\mathrm{p} 53$ proteins in response to camptothecin, a DNA-damaging agent that is known to induce cell death through a p53-dependent mechanism (Xiang et al., 1998; Morris et al., 2001). Wild-type and mutant p53 proteins were expressed in p53-deficient neurons to determine whether they could reestablish sensitivity to DNA damage-induced apoptosis. CGNs were transduced with adenoviral vectors expressing 
A.

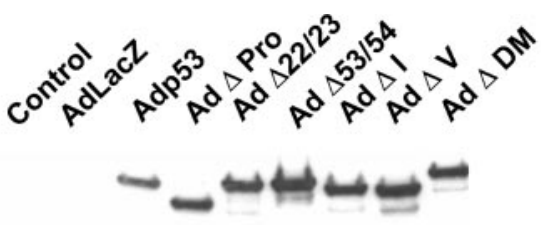

p53

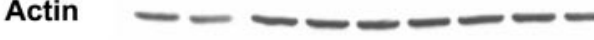

B.

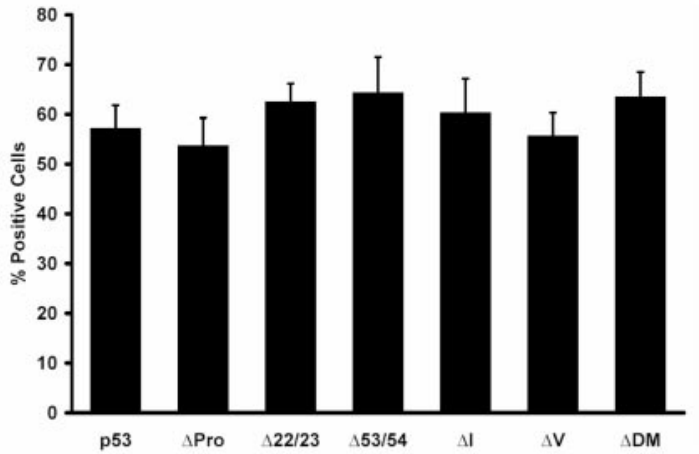

C.

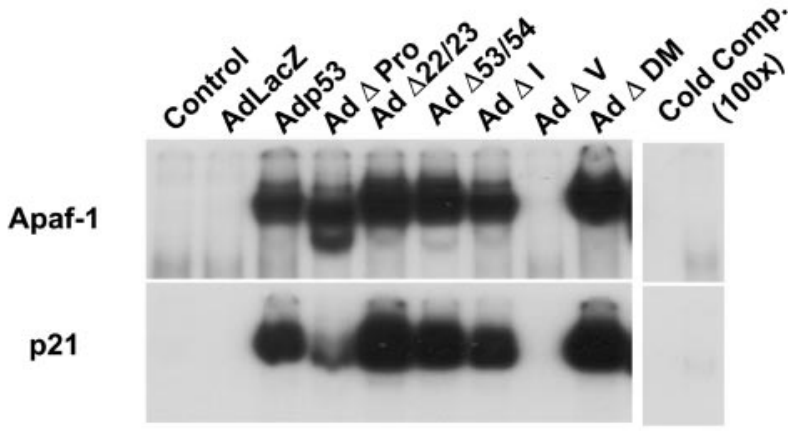

Figure 2. P53 mutant proteins are stable, expressed at comparable levels, and retain the appropriate protein conformation. $A$, Western blot showing comparable expression levels of p53 mutant proteins. CGNs were infected at $25 \mathrm{MOl}$ with the indicated Ad-p53 construct, and protein lysates were collected at $36 \mathrm{hr}$ after infection (30 $\mu \mathrm{g}$ protein/lane). B, CGNs were infected with the indicated Ad-p53 construct at $25 \mathrm{MOl}$. After $36 \mathrm{hr}$, neurons were fixed and immunostained for p53 and counterstained with Hoechst. Data represent the mean and SD of three independent experiments. C, EMSA. Protein was extracted from CGNs $36 \mathrm{hr}$ after infection with the indicated Ad-p53 constructs. p53-binding activity to the APAF1 and p21 p53 response elements were assayed by EMSA. Binding reactions were performed with neuronal extracts $(10-20 \mu \mathrm{g}$ protein) and the indicated oligonucleotides in the presence of $\mathrm{p} 53$ antibody (Ab1). To control for binding specificity, a 100-fold excess of unlabeled oligonucleotide was added to the binding reaction and incubated for $20 \mathrm{~min}$ before the addition of labeled probe. All p53 constructs tested efficiently bound DNA, with the exception of $\Delta V$, which inactivates DNA binding $(n=3)$.

wild-type or mutant $\mathrm{p} 53$ proteins and then challenged with the DNA-damaging agent camptothecin. Cell death was monitored within $24 \mathrm{hr}$ of drug treatment to minimize the contribution of p53 expression alone to the death response. Consistent with previous studies, $76 \%$ of wild-type neurons treated with camptothecin underwent apoptosis after $24 \mathrm{hr}$ (Fig. 5). Uninfected or AdGFP-infected p53-deficient cells exhibited only $10-15 \%$ cell death (Fig. 5). Cells reconstituted with wild-type p53 (Ad-p53wt) or a 53 mutant lacking the MDM2-binding domain (Ad-p53 II) were rescued in their apoptotic response revealing 64 and 57\% cell death, respectively. Cells expressing p53 with a mutation in the proline-rich motif (Ad-p53 $\Delta$ Pro) revealed an intermediate apoptotic response of $37 \%$ cell death. Interestingly, mutants lacking either one of the transactivation domains (Ad-p53 22/23, Ad-p53 553/54) also exhibited intermediate levels of apoptosis
A.

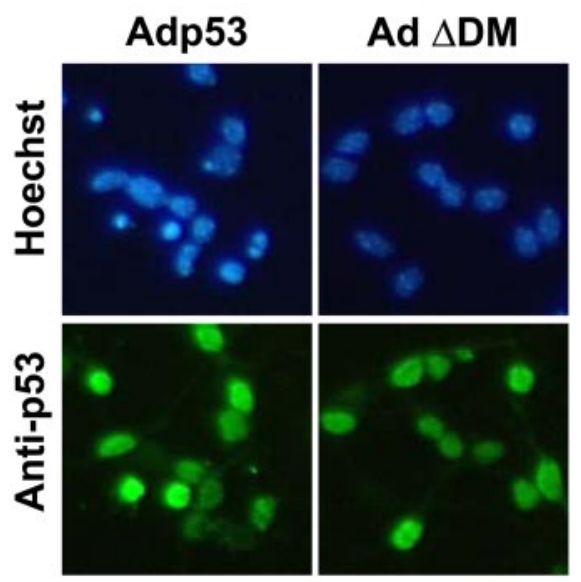

B.

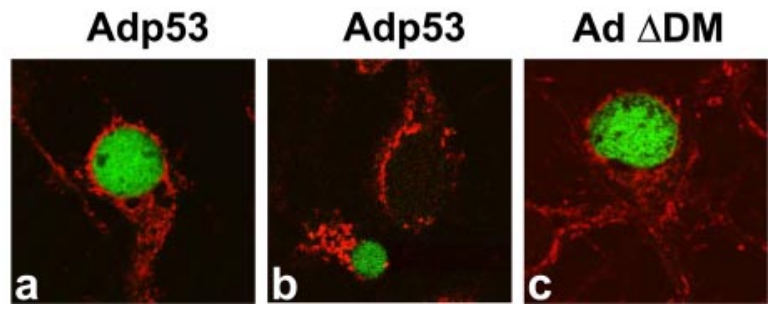

Figure 3. $p 53$ mutant proteins localize to the nucleus. Cortical neurons were infected with Ad-p53WT or Ad-p53DM at $25 \mathrm{MOl}$. After $48 \mathrm{hr}$, neurons were fixed and immunostained for $\mathrm{p} 53$ $(A, B)$ and/or mitochondrial-specific CoxIV $(B)$ or counterstained with Hoechst $(A)$. p53 remained localized to the nucleus even under conditions of cell death, as denoted by condensed nuclei $(b)$.

(Fig. 5). Consistent with our results obtained by direct overexpression, mutation of the first transactivation domain, p53 $22 /$ 23 , severely impaired the ability to rescue apoptosis, exhibiting only a slightly higher kill than p53-deficient neurons (19\% cell death). In contrast, cells expressing the mutation in the second transactivation domain, p53 $553-54$, resulted in a partial rescue of the death response such that $32 \%$ of neurons had undergone cell death (Fig. 5). This corresponded to approximately half the activity obtained after reconstitution with wild-type p53. In contrast, expression of $\mathrm{p} 53$ proteins either lacking function of both transactivation domains (p53DM), or DNA-binding activity $(\mathrm{p} 53 \Delta \mathrm{V})$ could not restore the apoptotic response to camptothecin. Consistent with results obtained by direct expression of the p53 mutants in neurons, reconstitution experiments revealed that the transcriptional activity of p53 was essential for the induction of neuronal cell death after DNA damage. Although p53 contains two distinct transactivation domains, there appears to be a difference in the ability of these domains to induce apoptosis. The finding that the ADI mutant exhibited a significantly greater defect than ADII in the rescue of the apoptotic response suggests that ADI may play a more prominent role in the induction of proapoptotic genes. We therefore asked whether these p53 mutants could induce known p53 transcriptional players effectively.

Transactivation mutants of $\mathrm{p} 53$ activate common and distinct proapoptotic targets

The results presented above suggest that the transactivation function is essential for p53-mediated neuronal cell death; however, 
A.

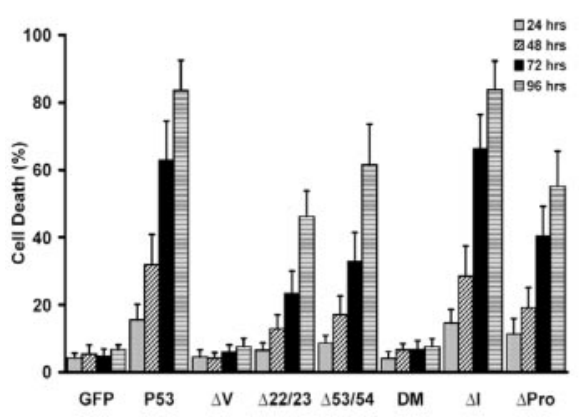

C.

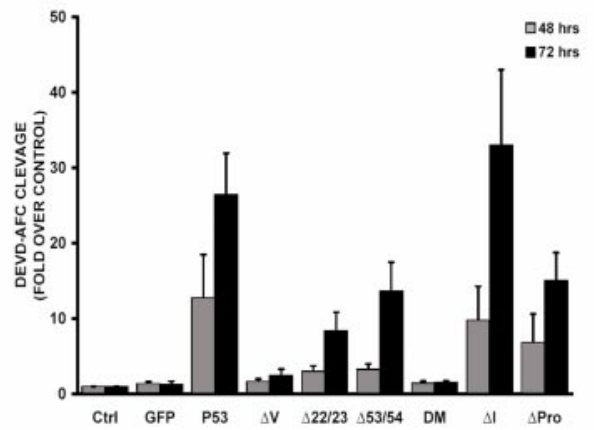

$\Delta \mathrm{DM}$

B.

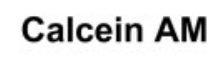

Ethidium Homodimer

P53

$\Delta 22 / 23$
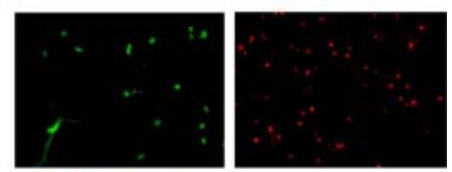

$\Delta 53 / 54$
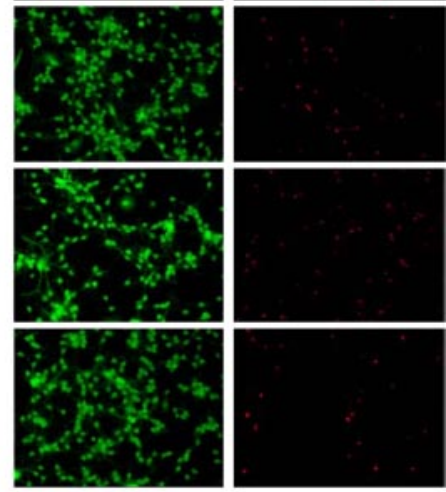

D.

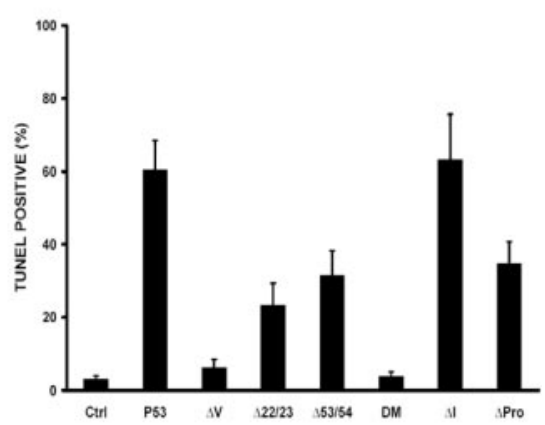

Figure 4. Transactivation domain 1 of $\mathrm{p} 53$ is essential for the induction of neuronal cell death. CGNs were infected with wild-type Ad-p53 or p53 mutant constructs at $25 \mathrm{MOI}$. A, LIVE/DEAD viability/cytotoxicity assay (Molecular Probes) was preformed at 24, 48, 72, and $96 \mathrm{hr}$ after infection. B, Photomicrographs of LIVE/DEAD cell assay. Scale bar, $100 \mu \mathrm{m}$. C, Caspase-3 activity was measured at 48 and $72 \mathrm{hr}$ by DEVD-AFC cleavage. $D$, The fraction of TUNEL-positive cells was measured $72 \mathrm{hr}$ after infection. Data represent the mean and SD of five independent experiments $(n=5)$.

the two transactivation domains exhibit slightly differential apoptotic effects. We therefore asked whether there might be a difference in the target genes activated by these two domains. The induction of a series of proapoptotic $p 53$ target genes by each of the p53 mutants was examined and compared using semiquantitative RTPCR. The proapoptotic genes examined were Noxa (Oda et al., 2000), Apaf-1 (Fortin et al., 2001), PUMA (Han et al., 2001; Nakano and Vousden, 2001; Yu et al., 2001), and Perp (Attardi et al., 2000). Consistent with caspase activation and survival assays, maximal activation of proapoptotic genes was found with wild-type p53 and the MDM2-binding mutant (Adp53 $\mathrm{I}$ ) (Fig. 6). In contrast, no induction over GFP controls was found with the DNA-binding mutant (Ad-p53 $\Delta \mathrm{V}$ ) or Adp53 DM lacking both transactivation domains. Cells expressing p53 lacking the proline-rich motif Ad-p53 $\Delta$ Pro exhibited target-specific differences in gene induction relative to GFP controls. Some of the transcriptional targets for p53 could be equally induced by either one of the transactivation domains. For example, the targets Noxa, Apaf-1, and Perp could be efficiently induced by either one of the two transactivation domains. In contrast, there was a significant loss of activity in the induction of PUMA when either one of the transactivation domains were lost. Indeed PUMA mRNA levels were close to control levels, in cells expressing either the ADI or the ADII mutant.

Apoptotic response in neurons carrying a targeted mutation in activation domain 1

Based on caspase assays, apoptotic activity, and reconstitution assays, it appears that for Puma-mediated induction in vitro, both activation domains are important for the initiation of apoptosis in neuronal cells. We next asked whether a mutation in one of the existing transactivation domains in the endogenous p53 gene is sufficient to abrogate the p53-mediated apoptotic response as seen in the overexpression and reconstitution experiments above. To answer this question, we used p53QS knock-in mice that express a 553 protein containing a double point mutation of amino acid residues 25 (Leu-Gln) and 26 (Trp-Ser) analogous to the $22 / 23$ mutation in the human p53 protein (Jimenez et al., 2000). Primary cortical neurons were cultured from p53QS mice along with their heterozygous littermates. As a basis for comparison, cells were also cultured from p53 knock-out and wild-type mice of the same genetic background. Cell survival was assessed at 24 or $48 \mathrm{hr}$ after camptothecin treatment to determine whether p53QS neurons were affected in their response to DNA damage (Fig. 7A). Although $86 \%$ of wild-type cells had undergone apoptosis by $48 \mathrm{hr}$, only $13 \%$ of p53 null cells were apoptotic. Neurons homozygous for the QS mutation exhibited only $16 \%$ cell death, a response similar to p53-deficient neurons. Mice heterozygous for the QS mutation exhibited 83\% cell death similar
Figure 5. Reconstitution of responsiveness to DNA damage-induced apoptosis in p53deficient neurons. Cortical neurons obtained from p53-deficient mice or wild-type littermates were infected with Ad-p53 or Ad-p53 mutant constructs and $16 \mathrm{hr}$ later were challenged with $10 \mu \mathrm{M}$ camptothecin. The reconstitution of apoptotic cell death was determined by LIVE/DEAD assay $24 \mathrm{hr}$ after treatment. ${ }^{*} p<0.05$ by two-way ANOVA compared with wild type, followed by $t$ test. Data represent the mean and SD of three independent experiments $(n=3)$. Ctrl, Control. 


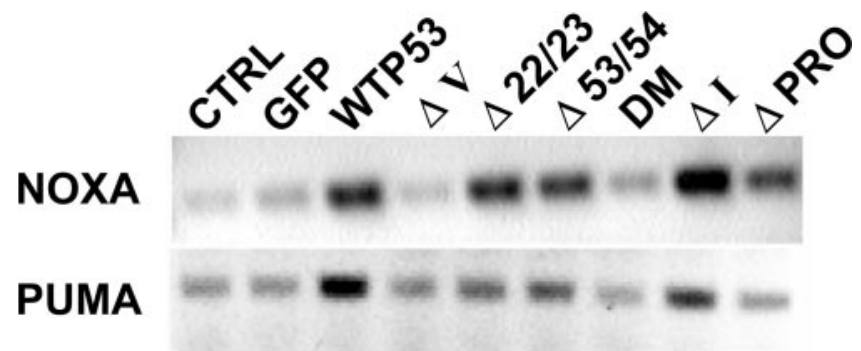

APAF-1

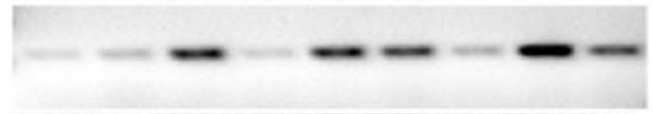

PERP

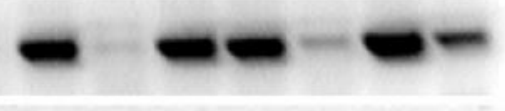

S12

Figure 6. p53 mutants cause differential upregulation of target genes in CGNs. Total RNA was extracted from CGNs $40 \mathrm{hr}$ after infection with Ad-p53 or Ad-p53 mutant constructs as indicated and analyzed for Noxa, Apaf-1, PUMA, and Perp or S12 expression using semiquantitative RT-PCR. CTRL, Control.

to that observed in wild-type cells. This suggests that ADI is essential for p53 induction of apoptosis in postmitotic neurons.

We then examined the ability of the $\mathrm{p} 53 \mathrm{Q} S$ protein to induce expression of $p 53$ target genes after camptothecin treatment. We specifically examined the two $p 53$ target genes, PUMA and Noxa, because of their differential induction profiles in response to adenoviral-mediated expression of p53. In wild-type mice, both Noxa and PUMA are upregulated in response to camptothecin treatment (Fig. 7B). Although camptothecin-induced expression of Noxa mRNA was essentially unaffected in p53QS neurons relative to wild-type neurons, upregulation of PUMA mRNA was completely abrogated (Fig. $7 C$ ). These results suggest that, similar to the response seen with ectopically expressed p53 mutants, the endogenous mutant $\mathrm{p} 53 \mathrm{QS}$ is unable to activate expression of PUMA. AD1, therefore, is essential for the transcriptional induction of PUMA and neuronal apoptosis in response to DNA damage-induced injury.

PUMA is a potent inducer of neuronal cell death

Because PUMA upregulation correlated closely with the ability to induce apoptosis, whereas Noxa induction did not, we directly tested the apoptotic activity of each of these $\mathrm{BH} 3$-only proteins in postmitotic neurons. To test this, adenoviral vectors were constructed carrying Noxa and PUMA expression cassettes. Western blots were performed to confirm the efficient expression of these proteins (Fig. $8 A, B$ ). CGNs expressed Noxa as early as $24 \mathrm{hr}$ after infection, with high expression levels present at $48 \mathrm{hr}$. In contrast, PUMA expression was not readily detectable in neurons (data not shown), likely because of its ability to rapidly induce cell death (Fig. 9C). Consistent with this, PUMA could be efficiently expressed in HEK 293 cells, which are deficient in BAX function because of the presence of E1B (Graham et al., 1977) (Fig. 8B). Because of the strong proapoptotic affect of Puma, immunohistochemistry of both Noxa and Puma was performed in Baxdeficient neurons to verify that both $\mathrm{BH} 3$-only proteins were equally well expressed. Immunohistochemistry revealed efficient transduction levels of $65-70 \%$ for both adenoviral constructs (Fig. $8 C$ ). To examine the ability of these $\mathrm{BH} 3$-only proteins to induce neuronal apoptosis, primary neurons were infected with
A.

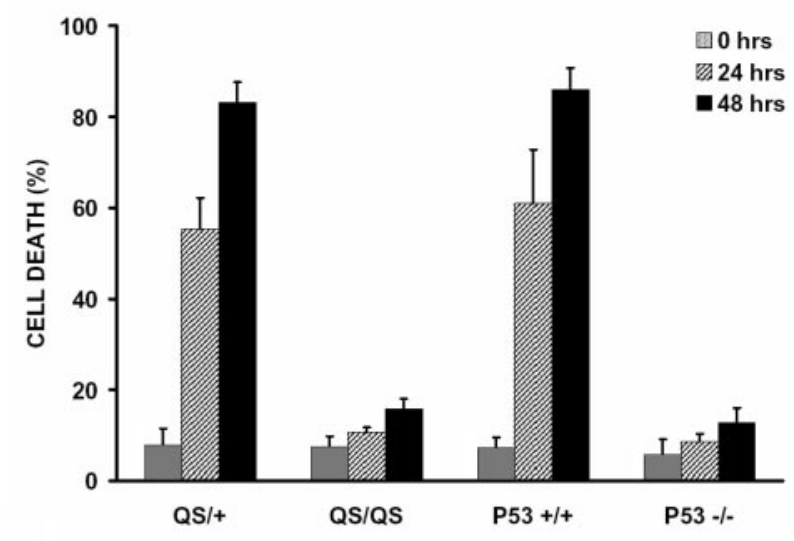

B.

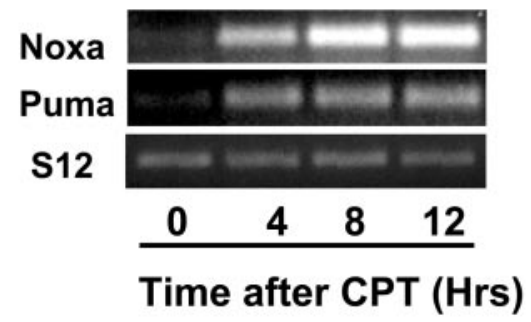

C.

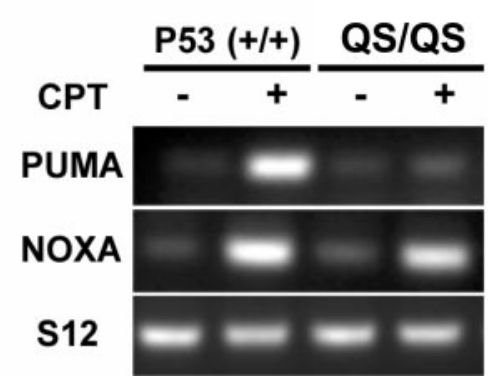

Figure 7. Transactivation domain 1 of $\mathrm{p} 53$ is essential for the induction of neuronal cell death in vivo. A, Cortical neurons obtained from QS mice, p53-deficient mice, or wild-type littermates were treated with $10 \mu \mathrm{m}$ camptothecin, and cell survival was determined by LIVE/ DEAD assay at the indicated times. Cell death is reported as a percentage of corresponding untreated control cultures. Data represent the mean and SD from three independent experiments $(n=3)$. B, Total RNA from cortical neurons from CD1 mice treated with camptothecin was collected and analyzed at the indicated times for Noxa, PUMA, and S12 expression using semiquantitative RT-PCR. C, Cortical neurons from QS mice, p53-deficient mice, or wild-type littermates were treated with $10 \mu \mathrm{m}$ camptothecin, and after $9 \mathrm{hr}$, total RNA was collected and analyzed for Noxa, PUMA, and S12 expression using semiquantitative RT-PCR.

Noxa or PUMA vectors at varying doses to generate a doseresponse curve (Fig. 9A,B). Our survival assays clearly showed that PUMA induced a rapid apoptotic response, such that at 12.5 multiplicities of infection (MOI), $>50 \%$ of cells were dead at 24 hr. In contrast, Noxa failed to induce significant apoptosis at 24 hr even at 200 MOI. To determine whether Noxa induced a delayed apoptotic response, a time course survival assay was performed with CGNs infected at 50 MOI with Noxa, PUMA, or a GFP control vector (Fig. 9C). Again, our results demonstrated that cultures expressing PUMA exhibited a rapid apoptotic response such that $>80 \%$ of cells were dead by $48 \mathrm{hr}$. Cells expressing Noxa, however, exhibited minimal cell death even at $96 \mathrm{hr}$ after infection. In conclusion, these results demonstrate that the p53 target gene PUMA is a potent inducer of apoptosis, whereas Noxa on its own is inefficient at triggering cell death. 
A.

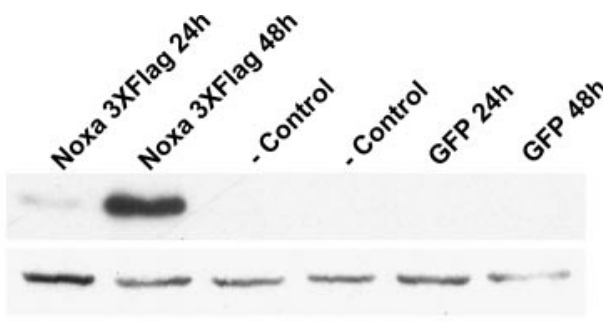

$\alpha$ Flag

$\alpha$ Actin

B.

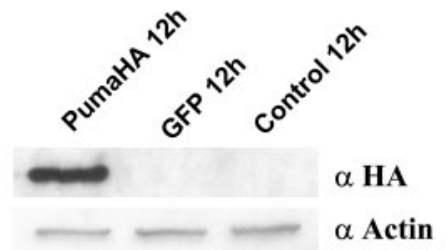

C.
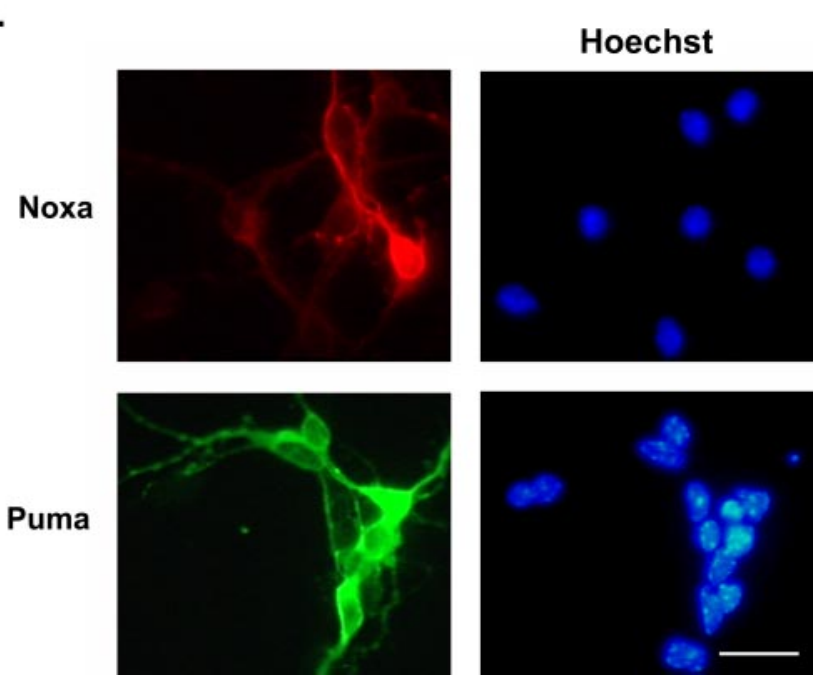

Figure 8. Upregulation of Noxa and PUMA mRNA in p53-mediated neuronal cell death. Western blots showing efficient transduction of Ad-Noxa3XFlag and AD-PumaHA are shown. $A$, CGNs were infected with Ad-Noxa3XFlag or Ad-GFP at $50 \mathrm{MOl}$. Protein lysates were collected 48 hr after infection and were blotted for Noxa expression with an antibody against Flag or for actin as a loading control. B, HEK 293 cells were infected with Ad-PumaHA or Ad-GFP at $25 \mathrm{MOI}$. Protein lysates were collected $12 \mathrm{hr}$ after infection and were blotted for PUMA expression with an antibody against $H A$ or for actin as a loading control. C, Neurons were infected with Ad-NoxaFlag or Ad-PumaHA at $50 \mathrm{MOI}$. After $24 \mathrm{hr}$, neurons were fixed and immunostained for Flag or HA and counterstained with Hoechst. Scale bar, $25 \mu \mathrm{m}$. Figures are a representative of three independent experiments $(n=3)$.

PUMA is required for $\mathrm{p} 53$-mediated neuronal cell death

We have shown that the upregulation of PUMA by p 53 requires the presence of both transactivation domains and that enforced expression of PUMA is sufficient to induce neuronal cell death. To determine whether PUMA is essential for p53-mediated apoptosis, we infected CGNs derived from PUMA-deficient mice or wild-type littermates with adenovirus expressing either p53, p53 DM, or GFP. In Figure 10 we demonstrate that PUMAdeficient neurons are significantly more resistant to p53-induced cell death at 48,72, and $96 \mathrm{hr}$, relative to littermate controls. These results demonstrate that the upregulation of PUMA is required for p53-induced neuronal apoptosis.

In summary, we have shown that ADI of $\mathrm{p} 53$, within residues 1-42 (Unger et al., 1993; Lin et al., 1994; Chang et al., 1995), is essential to induce neuronal cell death because of its efficacy at
A.
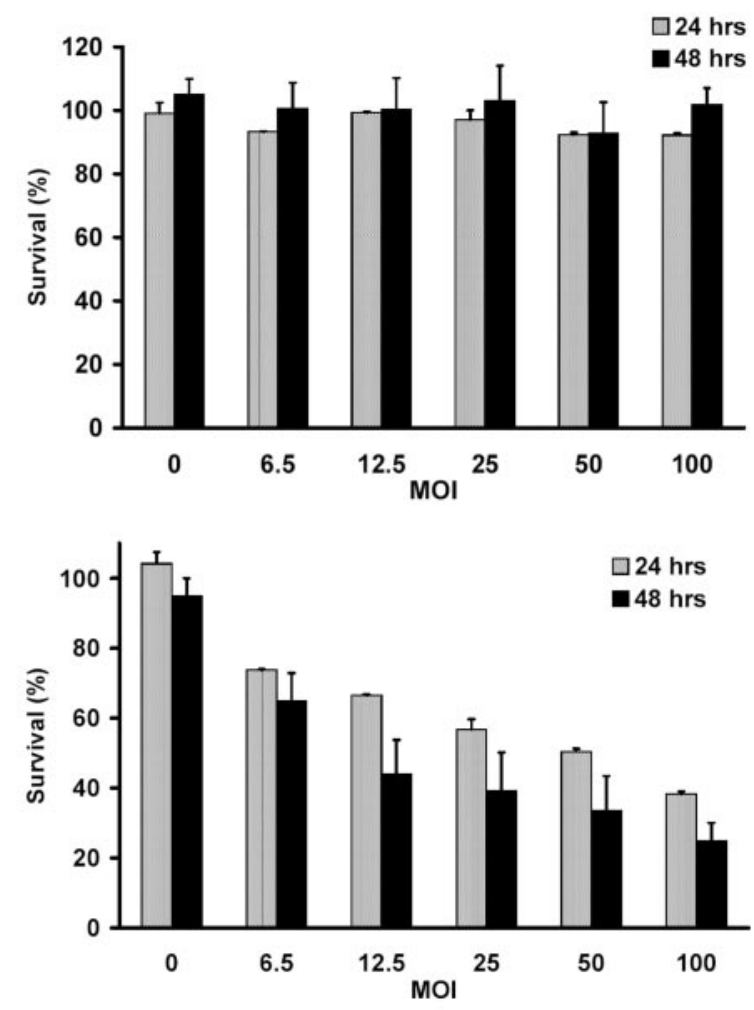

C.

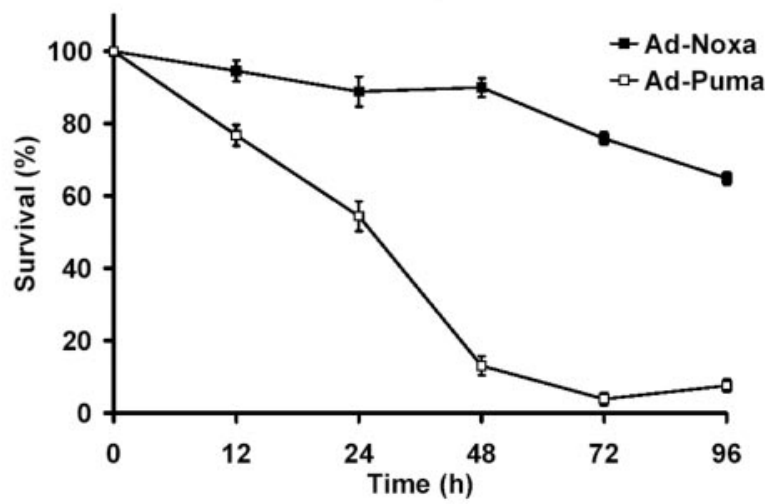

Figure 9. Forced expression of PUMA, but not Noxa, is sufficient to induce neuronal apoptosis. CGNs were infected with Ad-Noxa3XFlag $(A)$, Ad-PumaHA ( $B)$, or Ad-GFP control at the indicated $\mathrm{MOl}$. Neuronal survival was determined at the indicated times by MTT assay. Survival is measured as a percentage of Ad-GFP-treated control cells. C, CGNs were infected with AdNoxa3XFlag or Ad-PumaHA at $50 \mathrm{MOI}$. Neuronal survival was determined at the indicated times by MTT assay. Survival was measured as a percentage of Ad-GFP-treated control cells. Data represent the mean and SD from three independent experiments $(n=3)$.

inducing required proapoptotic target genes such as PUMA. The importance of PUMA in p53-mediated neuronal cell death is underscored by the fact that PUMA-deficient cells are resistant to apoptosis induced by p53. Thus, we have shown that PUMA is essential for the downstream propagation of the apoptotic cascade initiated by the transactivation function of $\mathrm{p} 53$.

\section{Discussion}

The involvement of the p53 tumor suppressor has been demonstrated in neuronal cell death induced by acute injury and neurodegenerative diseases (Chopp et al., 1992; de la Monte et al., 1997, 1998; Banasiak and Haddad, 1998; McGahan et al., 1998; Halterman and Federoff, 1999; Watanabe et al., 1999; Cheng et al., 2003). Understanding the underlying apoptotic pathways is 

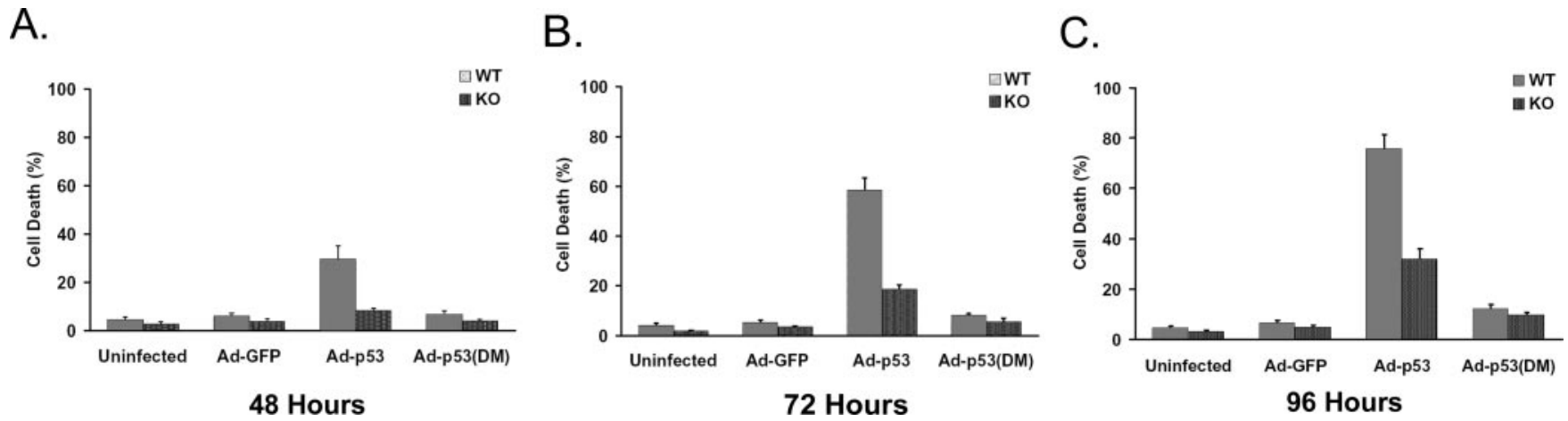

Figure 10. Upregulation of PUMA is essential for the induction of p53-mediated neuronal cell death. CGNs obtained from PUMA-deficient mice or control littermates were infected with wild-type Ad-p53, p53 $\triangle \mathrm{DM}$, or GFP constructs at $15 \mathrm{M} 0$ I. LIVE/DEAD viability/cytotoxicity assay (Molecular Probes) was preformed at $48 \mathrm{hr}(A), 72 \mathrm{hr}(B)$, and $96 \mathrm{hr}(C)$ after infection. Data represent the mean and SD of three independent experiments $(n=3)$.

essential for the development of effective neuroprotective therapies. Despite the importance of p53 in neuronal apoptosis, little is known regarding the mechanisms by which p53 induces cell death. The results of our studies support a number of conclusions. First, we showed that p53-mediated transactivation is essential for the induction of neuronal cell death. Second, we demonstrated that ADI of p53 is essential for the induction of target genes involved in neuronal apoptosis. Third, we showed that the induction of the proapoptotic $\mathrm{BH} 3$-only protein PUMA requires the presence of both activation domains to trigger neuronal apoptosis. Fourth, we showed that PUMA is required for p53mediated neuronal cell death. These studies suggest that PUMA may provide a therapeutic target for the treatment of acute neuronal injury.

Recent studies have revealed that p53 is a multifunctional protein and can induce apoptosis by diverse mechanisms. Most notably, p53 has recently been shown to induce apoptosis exclusively at the mitochondria (Mihara et al., 2003; Bonini et al., 2004). In these studies, p53 mutants were constructed that failed to translocate to the nucleus and to activate the transcription of known p53 target genes. These p53 mutants could, however, translocate to the mitochondria where they were shown to sequester antiapoptotic BCL family protein and induce apoptosis (Mihara et al., 2003). Also, when glial cells were treated with pifithrin- $\alpha$, a compound that has been reported to protect neurons from ischemic or excitotoxic insult by specifically inhibiting p53 DNA-binding ability (Culmsee et al., 2001a,b), p53 was still able to induce apoptosis through direct activity at the mitochondria (Bonini et al., 2004). Although the mitochondrial-mediated mechanism appears to be important in certain cell types and perhaps in response to specific stimuli, our studies demonstrate that this is not essential for the induction of neuronal apoptosis. Examination of double-stained neuronal cells by confocal microscopy did not reveal any colocalization of p53 with the mitochondria, even when undergoing cell death, as determined by condensed nuclei. Consistent with the absence of direct p53mitochondrial apoptotic activity, inactivation of ADI resulted in a loss of apoptotic activity when the mutant p $53 \Delta 22 / 23$ was overexpressed. Furthermore, mutants lacking the first activation domain failed to reconstitute p53 responsiveness in p53-deficient cells exposed to camptothecin. Mutation of ADI in the endogenous gene $p 53 Q S$ leads to a complete loss of apoptotic activity in response to DNA damage. It should be noted, however, that the experiments presented here were limited to apoptosis induced by enforced p53 expression or DNA damage but cannot rule out the possibility that different types of p53-mediated death stimuli may recruit other transcription-independent mechanisms. These results highlight the fact that p53-induced apoptotic mechanisms are cell type specific and that p53 transactivation function is critical for neuronal apoptosis.

P53 contains two distinct transcription activation domains, and the importance of these domains in the induction of apoptosis appears to be dependent on the cell type examined. Although ADI has been shown to be important for cell death in primary thymocytes (Chao et al., 2000; Jimenez et al., 2000), studies using human lung carcinoma cells revealed that ADI was dispensable for apoptosis. In this instance, ADII was shown to be required (Zhu et al., 1998).

Recently, studies have shown that p53-mediated transcriptional activity correlated directly with the amount of p53 interaction with p300/CREB-binding protein (p300/CBP) (Liu et al., 2003). Furthermore, both activation domains, and to a lesser extent the proline-rich domain of p53, are necessary for interaction with p300/CBP and for histone acetylation of the proximal p21 promoter required for p21 transactivation (Liu et al., 2003). The loss of p300/CBP-binding activity could account for the decreased levels of apoptotic activity observed in the ADI and $\Delta$ Pro mutants. Although the proline-rich region has been shown previously to be necessary for apoptosis (Zhu et al., 1999; Baptiste et al., 2002), other data suggest that its deletion may influence function by altering local protein structure (Edwards et al., 2003). This alteration of protein structure leads to differential promoter interactions and therefore may actually be dispensable for apoptotic activity (Edwards et al., 2003). The importance of ADI and ADII may depend on the subset of proapoptotic genes induced, and the requirement of $p 53$ target genes may be cell type specific. Using site-directed p53 mutants, we have shown that each transactivation domain has independent effects on the induction of proapoptotic $p 53$ target genes. Most notably, Noxa is readily induced by mutants carrying a mutation in ADI or ADII, whereas PUMA can only be induced when both transactivation domains are present. Based on these findings, we examined the proapoptotic activity of $\mathrm{BH} 3$-only proteins Noxa and PUMA in postmitotic neurons.

The $\mathrm{BH} 3$-only members of the $\mathrm{Bcl}-2$ family of proteins are a unique group that only share a common nine amino acid $\mathrm{BH} 3$ domain with the other family members (Huang and Strasser, 2000; Puthalakath and Strasser, 2002). This BH3 domain has been shown to be required for the interaction with other Bcl-2 family members in the induction of apoptosis (Wang et al., 1996; Cheng et al., 2001; Zong et al., 2001). Previous studies have shown that Noxa and PUMA, two members of the BH3-only 
family, are upregulated under conditions of p53-mediated cell death in mouse embryonic fibroblasts (Oda et al., 2000) and colon cancer cell lines (Han et al., 2001; Nakano and Vousden, 2001; Yu et al., 2001, 2003). Studies with mice carrying a null mutation for PUMA have shown that it is a key player in the apoptotic pathway. PUMA deficiency confers similar protection against apoptotic stimulus as seen with p53 deficiency (Jeffers et al., 2003; Villunger et al., 2003). Work done in cell lines has also shown that PUMA may be regulated by factors other than p53, such as E2F-1 (Hershko and Ginsberg, 2003) and p73 (Melino et al., 2003), emphasizing its importance in the apoptotic pathway. The primary function of the Noxa protein seems to be at the mitochondrial level (Seo et al., 2003). Recent work with Noxadeficient mice suggests that it may play a minor role in the apoptotic pathway in fibroblasts but that it is dispensable in other tissues (Villunger et al., 2003). Several results in the present study suggest that Noxa is not likely to play an essential role in p53mediated neuronal cell death. First, Noxa was efficiently induced by ectopic expression of p53 mutants that are defective in the induction of cell death. Second, Noxa was still induced after camptothecin treatment in p53QS neurons, yet these cells did not undergo cell death. Finally, enforced expression of Noxa was inefficient at triggering neuronal apoptosis. In contrast, p53mediated induction of PUMA strongly correlated with apoptosis, and ectopic expression of PUMA itself was sufficient to induce apoptosis. Furthermore, PUMA-deficient CGNs were found to be substantially more resistant to cell death induced by p53 overexpression than littermate controls even at time points as late as $96 \mathrm{hr}$ after infection. Thus, our studies demonstrate that PUMA, unlike Noxa, is a potent inducer of neuronal apoptosis and plays a key role in neuronal injury-induced cell death.

The results demonstrate that $\mathrm{p} 53$ requires a functional transcriptional activation domain, specifically ADI, to induce the death of postmitotic neurons. Although multiple $p 53$ target genes are induced in neurons, the proapoptotic $\mathrm{BH} 3$-only protein PUMA is a potent inducer of apoptosis in neuronal injury. Our results show that upregulation of PUMA is a key determinant in p53-mediated neuronal cell death and suggest that PUMA may serve as a key therapeutic target for the treatment of acute brain injury.

\section{References}

Attardi LD, Lowe SW, Brugarolas J, Jacks T (1996) Transcriptional activation by $\mathrm{p} 53$, but not induction of the $\mathrm{p} 21$ gene, is essential for oncogenemediated apoptosis. EMBO J 15:3693-3701.

Attardi LD, Reczek EE, Cosmas C, Demicco EG, McCurrach ME, Lowe SW, Jacks T (2000) PERP, an apoptosis-associated target of p53, is a novel member of the PMP-22/gas3 family. Genes Dev 14:704-718.

Banasiak KJ, Haddad GG (1998) Hypoxia-induced apoptosis: effect of hypoxic severity and role of p53 in neuronal cell death. Brain Res 797:295-304.

Baptiste N, Friedlander P, Chen X, Prives C (2002) The proline-rich domain of $\mathrm{p} 53$ is required for cooperation with anti-neoplastic agents to promote apoptosis of tumor cells. Oncogene 21:9-21.

Bennett M, Macdonald K, Chan SW, Luzio JP, Simari R, Weissberg P (1998) Cell surface trafficking of Fas: a rapid mechanism of p53-mediated apoptosis. Science 282:290-293.

Bonini P, Cicconi S, Cardinale A, Vitale C, Serafino AL, Ciotti MT, Marlier LN (2004) Oxidative stress induces p53-mediated apoptosis in glia: p53 transcription-independent way to die. J Neurosci Res 75:83-95.

Caelles C, Helmberg A, Karin M (1994) p53-dependent apoptosis in the absence of transcriptional activation of p53-target genes. Nature 370:220-223.

Chang H, Blondal JA, Benchimol S, Minden MD, Messner HA (1995) p53 mutations, c-myc and bcl-2 rearrangements in human non-Hodgkin's lymphoma cell lines. Leuk Lymphoma 19:165-171.
Chao C, Saito S, Kang J, Anderson CW, Appella E, Xu Y (2000) p53 transcriptional activity is essential for p53-dependent apoptosis following DNA damage. EMBO J 19:4967-4975.

Chen X, Ko LJ, Jayaraman L, Prives C (1996) p53 levels, functional domains, and DNA damage determine the extent of the apoptotic response of tumor cells. Genes Dev 10:2438-2451.

Cheng EH, Wei MC, Weiler S, Flavell RA, Mak TW, Lindsten T, Korsmeyer SJ (2001) BCL-2, BCL-X(L) sequester BH3 domain-only molecules preventing BAX- and BAK-mediated mitochondrial apoptosis. Mol Cell 8:705-711.

Cheng T, Liu D, Griffin JH, Fernandez JA, Castellino F, Rosen ED, Fukudome K, Zlokovic BV (2003) Activated protein C blocks p53-mediated apoptosis in ischemic human brain endothelium and is neuroprotective. Nat Med 9:338-342.

Chipuk JE, Kuwana T, Bouchier-Hayes L, Droin NM, Newmeyer DD, Schuler M, Green DR (2004) Direct activation of Bax by p53 mediates mitochondrial membrane permeabilization and apoptosis. Science 303:1010-1014.

Chopp M, Li Y, Zhang ZG, Freytag SO (1992) p53 expression in brain after middle cerebral artery occlusion in the rat. Biochem Biophys Res Commun 182:1201-1207.

Cregan SP, MacLaurin JG, Craig CG, Robertson GS, Nicholson DW, Park DS, Slack RS (1999) Bax-dependent caspase-3 activation is a key determinant in p53-induced apoptosis in neurons. J Neurosci 19:7860-7869.

Cregan SP, MacLaurin J, Gendron TF, Callaghan SM, Park DS, Parks RJ, Graham FL, Morley P, Slack RS (2000) Helper-dependent adenovirus vectors: their use as a gene delivery system to neurons. Gene Ther 7:1200-1209.

Crumrine RC, Thomas AL, Morgan PF (1994) Attenuation of p53 expression protects against focal ischemic damage in transgenic mice. J Cereb Blood Flow Metab 14:887-891.

Culmsee C, Bondada S, Mattson MP (2001a) Hippocampal neurons of mice deficient in DNA-dependent protein kinase exhibit increased vulnerability to DNA damage, oxidative stress and excitotoxicity. Brain Res Mol Brain Res 87:257-262.

Culmsee C, Zhu X, Yu QS, Chan SL, Camandola S, Guo Z, Greig NH, Mattson MP (2001b) A synthetic inhibitor of $\mathrm{p} 53$ protects neurons against death induced by ischemic and excitotoxic insults, and amyloid beta-peptide. J Neurochem 77:220-228.

de la Monte SM, Sohn YK, Wands JR (1997) Correlates of p53- and Fas (CD95)-mediated apoptosis in Alzheimer's disease. J Neurol Sci 152:73-83.

de la Monte SM, Sohn YK, Ganju N, Wands JR (1998) p53- and CD95associated apoptosis in neurodegenerative diseases. Lab Invest 78:401-411.

Ding HF, Lin YL, McGill G, Juo P, Zhu H, Blenis J, Yuan J, Fisher DE (2000) Essential role for caspase-8 in transcription-independent apoptosis triggered by p53. J Biol Chem 275:38905-38911.

Edwards SJ, Hananeia L, Eccles MR, Zhang YF, Braithwaite AW (2003) The proline-rich region of mouse p53 influences transactivation and apoptosis but is largely dispensable for these functions. Oncogene 22:4517-4523.

Fortin A, Cregan SP, MacLaurin JG, Kushwaha N, Hickman ES, Thompson CS, Hakim A, Albert PR, Cecconi F, Helin K, Park DS, Slack RS (2001) APAF1 is a key transcriptional target for p53 in the regulation of neuronal cell death. J Cell Biol 155:207-216.

Graham FL, Smiley J, Russell WC, Nairn R (1977) Characteristics of a human cell line transformed by DNA from human adenovirus type 5 . J Gen Virol 36:59-74.

Halterman MW, Federoff HJ (1999) HIF-1alpha and p53 promote hypoxiainduced delayed neuronal death in models of CNS ischemia. Exp Neurol 159:65-72.

Han J, Flemington C, Houghton AB, Gu Z, Zambetti GP, Lutz RJ, Zhu L, Chittenden T (2001) Expression of bbc3, a pro-apoptotic BH3-only gene, is regulated by diverse cell death and survival signals. Proc Natl Acad Sci USA 98:11318-11323.

Haupt Y, Rowan S, Shaulian E, Vousden KH, Oren M (1995) Induction of apoptosis in HeLa cells by trans-activation-deficient p53. Genes Dev 9:2170-2183.

Hershko T, Ginsberg D (2003) Up-regulation of BH3-only proteins by E2F1: role in apoptosis. J Biol Chem 279:8627-8634.

Huang DC, Strasser A (2000) BH3-Only proteins-essential initiators of apoptotic cell death. Cell 103:839-842. 
Jeffers JR, Parganas E, Lee Y, Yang C, Wang J, Brennan J, MacLean KH, Han J, Chittenden T, Ihle JN, McKinnon PJ, Cleveland JL, Zambetti GP (2003) Puma is an essential mediator of p53-dependent and -independent apoptotic pathways. Cancer Cell 4:321-328.

Jimenez GS, Nister M, Stommel JM, Beeche M, Barcarse EA, Zhang XQ, O'Gorman S, Wahl GM (2000) A transactivation-deficient mouse model provides insights into Trp53 regulation and function. Nat Genet 26:37-43.

Koumenis C, Alarcon R, Hammond E, Sutphin P, Hoffman W, Murphy M, Derr J, Taya Y, Lowe SW, Kastan M, Giaccia A (2001) Regulation of p53 by hypoxia: dissociation of transcriptional repression and apoptosis from p53-dependent transactivation. Mol Cell Biol 21:1297-1310.

Kubbutat MH, Jones SN, Vousden KH (1997) Regulation of p53 stability by Mdm2. Nature 387:299-303.

Lin SR, Lee YJ, Tsai JH (1994) Mutations of the p53 gene in human functional adrenal neoplasms. J Clin Endocrinol Metab 78:483-491.

Liu G, Xia T, Chen X (2003) The activation domains, the proline-rich domain, and the $\mathrm{C}$-terminal basic domain in p53 are necessary for acetylation of histones on the proximal $\mathrm{p} 21$ promoter and interaction with $\mathrm{p} 300 /$ CREB-binding protein. J Biol Chem 278:17557-17565.

Macleod KF, Hu Y, Jacks T (1996) Loss of Rb activates both p53-dependent and independent cell death pathways in the developing mouse nervous system. EMBO J 15:6178-6188.

Marchenko ND, Zaika A, Moll UM (2000) Death signal-induced localization of $\mathrm{p} 53$ protein to mitochondria. A potential role in apoptotic signaling. J Biol Chem 275:16202-16212.

McGahan L, Hakim AM, Robertson GS (1998) Hippocampal Myc and p53 expression following transient global ischemia. Brain Res Mol Brain Res 56:133-145.

Melino G, Bernassola F, Ranalli M, Yee K, Zong WX, Corazzari M, Knight RA, Green DR, Thompson C, Vousden KH (2003) p73 induces apoptosis via PUMA transactivation and Bax mitochondrial translocation. J Biol Chem 279:8076-8083.

Mihara M, Erster S, Zaika A, Petrenko O, Chittenden T, Pancoska P, Moll UM (2003) p53 has a direct apoptogenic role at the mitochondria. Mol Cell 11:577-590.

Morris EJ, Keramaris E, Rideout HJ, Slack RS, Dyson NJ, Stefanis L, Park DS (2001) Cyclin-dependent kinases and P53 pathways are activated independently and mediate Bax activation in neurons after DNA damage. J Neurosci 21:5017-5026.

Morrison RS, Wenzel HJ, Kinoshita Y, Robbins CA, Donehower LA, Schwartzkroin PA (1996) Loss of the p53 tumor suppressor gene protects neurons from kainate-induced cell death. J Neurosci 16:1337-1345.

Murphy M, Hinman A, Levine AJ (1996) Wild-type p53 negatively regulates the expression of a microtubule-associated protein. Genes Dev 10:2971-2980.

Nakade K, Zheng H, Ganguli G, Buchwalter G, Gross C, Wasylyk B (2004) The tumor suppressor p53 inhibits Net, an effector of Ras/extracellular signal-regulated kinase signaling. Mol Cell Biol 24:1132-1142.

Nakano K, Vousden KH (2001) PUMA, a novel proapoptotic gene, is induced by p53. Mol Cell 7:683-694.

Oda E, Ohki R, Murasawa H, Nemoto J, Shibue T, Yamashita T, Tokino T, Taniguchi T, Tanaka N (2000) Noxa, a BH3-only member of the Bcl-2 family and candidate mediator of p53-induced apoptosis. Science 288:1053-1058.

Puthalakath H, Strasser A (2002) Keeping killers on a tight leash: transcrip- tional and post-translational control of the pro-apoptotic activity of $\mathrm{BH} 3$ only proteins. Cell Death Differ 9:505-512.

Ryan KM, Phillips AC, Vousden KH (2001) Regulation and function of the p53 tumor suppressor protein. Curr Opin Cell Biol 13:332-337.

Sansome C, Zaika A, Marchenko ND, Moll UM (2001) Hypoxia death stimulus induces translocation of $\mathrm{p} 53$ protein to mitochondria. Detection by immunofluorescence on whole cells. FEBS Lett 488:110-115.

Seo YW, Shin JN, Ko KH, Cha JH, Park JY, Lee BR, Yun CW, Kim YM, Seol DW, Kim DW, Yin XM, Kim TH (2003) The molecular mechanism of Noxa-induced mitochondrial dysfunction in p53-mediated cell death. J Biol Chem 278:48292-48299.

Seto E, Usheva A, Zambetti GP, Momand J, Horikoshi N, Weinmann R, Levine AJ, Shenk T (1992) Wild-type p53 binds to the TATA-binding protein and represses transcription. Proc Natl Acad Sci USA 89:12028-12032.

Slack RS, Belliveau DJ, Rosenberg M, Atwal J, Lochmuller H, Aloyz R, Haghighi A, Lach B, Seth P, Cooper E, Miller FD (1996) Adenovirusmediated gene transfer of the tumor suppressor, p53, induces apoptosis in postmitotic neurons. J Cell Biol 135:1085-1096.

Unger T, Mietz JA, Scheffner M, Yee CL, Howley PM (1993) Functional domains of wild-type and mutant p53 proteins involved in transcriptional regulation, transdominant inhibition, and transformation suppression. Mol Cell Biol 13:5186-5194.

Venot C, Maratrat M, Dureuil C, Conseiller E, Bracco L, Debussche L (1998) The requirement for the p53 proline-rich functional domain for mediation of apoptosis is correlated with specific PIG3 gene transactivation and with transcriptional repression. EMBO J 17:4668-4679.

Villunger A, Michalak EM, Coultas L, Mullauer F, Bock G, Ausserlechner MJ, Adams JM, Strasser A (2003) p53- and drug-induced apoptotic responses mediated by $\mathrm{BH} 3$-only proteins puma and noxa. Science 302:1036-1038.

Wang K, Yin XM, Chao DT, Milliman CL, Korsmeyer SJ (1996) BID: a novel BH3 domain-only death agonist. Genes Dev 10:2859-2869.

Watanabe H, Ohta S, Kumon Y, Sakaki S, Sakanaka M (1999) Increase in p53 protein expression following cortical infarction in the spontaneously hypertensive rat. Brain Res 837:38 - 45.

Xiang H, Kinoshita Y, Knudson CM, Korsmeyer SJ, Schwartzkroin PA, Morrison RS (1998) Bax involvement in p53-mediated neuronal cell death. J Neurosci 18:1363-1373.

Xu Y (2003) Regulation of p53 responses by post-translational modifications. Cell Death Differ 10:400-403.

Yu J, Zhang L, Hwang PM, Kinzler KW, Vogelstein B (2001) PUMA induces the rapid apoptosis of colorectal cancer cells. Mol Cell 7:673-682.

Yu J, Wang Z, Kinzler KW, Vogelstein B, Zhang L (2003) PUMA mediates the apoptotic response to 53 in colorectal cancer cells. Proc Natl Acad Sci USA 100:1931-1936.

Zhu J, Jiang J, Zhou W, Chen X (1998) The potential tumor suppressor p73 differentially regulates cellular p53 target genes. Cancer Res 58: 5061-5065.

Zhu J, Jiang J, Zhou W, Zhu K, Chen X (1999) Differential regulation of cellular target genes by p53 devoid of the PXXP motifs with impaired apoptotic activity. Oncogene 18:2149-2155.

Zhu J, Zhang S, Jiang J, Chen X (2000) Definition of the p53 functional domains necessary for inducing apoptosis. J Biol Chem 275:39927-39934.

Zong WX, Lindsten T, Ross AJ, MacGregor GR, Thompson CB (2001) $\mathrm{BH} 3$-only proteins that bind pro-survival $\mathrm{Bcl}-2$ family members fail to induce apoptosis in the absence of Bax and Bak. Genes Dev 15:1481-1486. 